\title{
KECEMASAN PADA DEWASA TUA (LANSIA) DALAM MENGHADAPI KEMATIAN
}

\author{
Widia Sri Ardias, Putri Intan Purwari \\ widiasri@uinib.ac.id; putripurwari@gmail.com \\ Universitas Islam Negeri Imam Bonjol Padang
}

\begin{abstract}
This study aims to look at the relationship between religiosity and death in older adults. The subject selection technique was done by purposive sampling consisting of 48 elderly adults. This study uses a non experimental quantitative approach. Hypothesis testing is done through the Pearson product moment correlation statistical test using the SPSS application. This study proves that there is a negative linear relationship between religiosity and anxiety of death in older adults. this proves that religious older adults have lower anxiety in the face of death. On the other hand, older adults with a low religious level proved to be more anxious in facing death.
\end{abstract}

Keywords: Religiosity, death anxiety, old adults

\section{A. PENDAHULUAN}

Religiusitas adalah kepercayaan, perasaan dan praktik yang erat kaitannya dengan agama. Pengertian religiusitas berdasarkan dimensi-dimensi yang dikemukakan oleh Glock dan Stark adalah seberapa jauh pengetahuan, seberapa kokoh keyakinan, seberapa tekun pelaksanaan ibadah dan seberapa dalam penghayatan agama yang dianut seseorang ${ }^{1}$. Religiusitas didefinisikan sebagai perasaan dan kesadaran akan hubungan dan ikatan kembali dengan Allah SWT ${ }^{2}$.

Religiusitas berasal dari kata latin yaitu, religiusita dan pertama kali muncul di Inggris pada abad ke-15 yang berarti kepercayaan atau agama. Ancok,

${ }^{1}$ D. \& Suroso, F. N. Ancok, 2005. Psikologi Islami: Solusi Islam Atas ProblemProblem Psikologi. Yogyakarta: Pustaka Pelajar.

${ }^{2}$ Ghufron dan Risnawati (2010). Teoriteori psikologi. Jogjakarta: Ar-Ruzz Media Group. menyebutkan religiusitas sebagai fenomena keberagamaan ${ }^{3}$. Religiusitas merupakan hal yang subjektif, pengalaman pribadi dan sangat sulit untuk mendefinisikan dengan pendekatan ilmu pengetahuan apapun ${ }^{4}$. Menurut Glock dan Stark (dalam Shpard, 2013) religiusitas adalah cara-cara individu mengekspresikan kepentingan agama dan keyakinannya ${ }^{5}$. Agama merupakan dasar bagi praktik religiusitas, sehingga individu yang religius akan senantiasa bertindak berdasarkan ajaran-ajaran dalam sistem kepercayaannya. Seseorang yang lemah religiusitasnya akan merasa cemas dan

\footnotetext{
${ }^{3}$ D., \& Suroso, F.N. Ancok, (2001). Psikologi islami. Yogyakarta: Pustaka Pelajar.

${ }^{4}$ Chamberlain, T.J., \& Hall, C.A. (2000). Realized religion. Radnor: Templetin Foundation Press.

${ }^{5}$ Shepard, J.M. (2013). Sociology. Belmont: Wadsworth Cengange Learning.
} 
takut dalam menghadapi kematian begitu juga sebaliknya.

Bahwa kecemasan terhadap kematian dapat dihubungkan dengan seseorang yang takut kesepian atau berada dalam lingkungan terbatas. Ketakutan terhadap kematian bisa disebabkan karena kematian sangat misterius, kehidupan setelah kematian yang dipersepsikan buruk atau memikirkan keadaan sanak saudara yang akan ditinggalkan ${ }^{6}$. Religiusitas dapat dihubungkan dengan kecemasan seseorang menghadapi kematian ${ }^{7}$ Kecemasan merupakan ketidakmampuan pengendalian kemampuan pikiran buruk yang berulangulang dan kecenderungan berfikir bahwa keadaan semakin memburuk. Tampler menyatakan bahwa kecemasan terjadi ketika seseorang memikirkan kematian.

Kecemasan terhadap kematian adalah sebuah fenomena kompleks yang mewakili banyak pemikiran dan emosi mengenai ketakutan kematian, kerusakan fisik dan mental, perasaan kesepian, kesedihan akibat kehilangan diri sendiri, kemarahan yang ekstrim, dan putus asa terhadap situasi yang tidak bisa dikontrol ${ }^{8}$. Kecemasan terhadap kematian adalah perasaan takut pada sesuatu yang akan terjadi, khawatir, ketakutan yang dihubungkan dengan kematian atau sekarat (proses kematian) ${ }^{9}$. Neimeyer

\footnotetext{
${ }^{6}$ Hidayat, K. (2013). Psikologi kematian. Jakarta: Noura Books.

${ }^{7}$ Wen, Y. (2010). Religiosity and Death Anxiety. The Journal of Human Resource and Adult Learning, Vol. 6 (2): 31-37.

${ }^{8}$ Firestone, R., Catlett, J. (2009). Beyond death anxiety. New York: Springer.

${ }^{9}$ Newfield, S.A., Hinz, M.D., Tilley, D.S., Sridaromont, K.L., \& Maramba, P.J. (2007). Nursing diagnosis adult, child, women's, mental health, gerontic, and home health considerations. Philadelphia: F.A. Davis Company.
}

(dalam Firestone \& Catlett) ${ }^{10}$ menjelaskan kecemasan terhadap kematian dan ketakutan terhadap kematian memiliki arti yang hampir sama yaitu ketakutan dan kekhawatiran yang ekstrim, kegelisahan yang berlebihan, dan berbagai macam ketakutan datangnya kematian. Jadi, kecemasan terhadap kematian adalah suatu emosi mengenai kematian yang kompleks yang mana diantarannya ketakutan pemikiran akan kesepian yang datang, rasa hampa, hilangnya suatu objek yang disayangi serta perubahan keadaan fisik dan psikologis yang semakin memburuk, dan proses kematian sehingga ia takut akan datangnya kematian.

Lebih lanjut dijelaskan oleh Maskawaih bahwa kecemasan menghadapi kematian melekat pada orang yang tidak mengetahui apa hakikat mati atau orang yang menyangka bahwa setelah jasmaninya rusak maka dirinya juga akan hilang atau orang yang mengira bahwa alam ini akan terus lestari sedangkan dirinya musnah ${ }^{11}$. Kecemasan terhadap kematian merupakan suatu kondisi emosional tidak menyenangkan yang dialami oleh seseorang secara subjektif ketika mulai memikirkan mengenai kematian yang akan dihadapi.

Kematian menurut Islam adalah kepastian. Hanya Allah yang mengetahui waktu dan caranya. Oleh sebab itu, manusia diharapkan senantiasa mempersiapkan diri dalam menghadapi kematian tersebut dengan bertaqwa kepada Allah dan berbuat kebaikan sepanjang hidupnya. Seperti firman Allah dalam surat Ali-Imran 185 berikut ini:

\footnotetext{
${ }^{10}$ Firestone, R., Catlett, J., Op.Cit.

${ }^{11}$ Wijayanti Ari, Lailatushifah Fatmah Siti Noor. 2012. Keberagamaan Hidup Dan Kecemasan Terhadap Kematian Terhadap Kematian Pada Orang Dengan Diabetes Meletus. Jurnal Insight Volume 10, No 1, Februari 2012.
} 


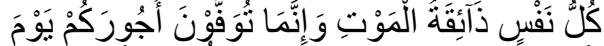

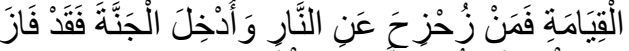

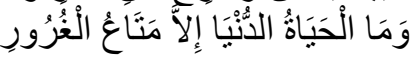

Artinya: "Tiap-tiap yang berjiwa akan merasakan mati. Dan sesungguhnya pada hari kiamat sajalah disempurnakan pahalamu. Barangsiapa dijauhkan dari neraka dan dimasukkan ke dalam surga, maka sungguh ia telah beruntung. Kehidupan dunia itu tidak lain hanyalah kesenangan yang memperdayakan" (Ali-Imran: 185).

Kekuasaan Allah meliputi segala sesuatu. Dia telah menetapkan kematian atas diri manusia. Sehingga bagaimanapun manusia berupaya menghindar darinya, kematian itu tetap akan mengejarnya. Allah Subhanahu wa Ta'ala berfirman:

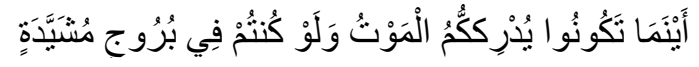

Artinya: Dimana saja kamu berada, kematian akan mendapatkan kamu, kendatipun kamu di dalam benteng yang tinggi lagi kokoh (An Nisa':78).

Seseorang yang religius dan memahami esensi ajaran agama tentunya sangat paham akan makna ayat-ayat di atas, sehingga mempersiapkan kematian bagi manusia pada dasarnya adalah suatu kewajiban yang tidak bisa dielakan lagi. Pada lansia, kewajiban ini semakin terasa dekat mengingat usia mereka semakin lanjut dan resiko akan kematian semakin besar bila dibandingkan dengan kelompok umur lainnya.

Populasi lanjut usia di Indonesia semangkin meningkat, baik jumlah obsolutnya maupun proposisinya. Peningkatan ini tentu membutuhkan perhatian yang lebih baik dari pemerintah, sektor swasta, organisasi non pemerintah, pragtisi kesehatan masyarakat pada umumnya, mengingat bahwa permasalahan yang dihadapi oleh mereka yang berusia lanjut pada banyak hal yang berbeda dengan yang dihadapi pada kelompok usia yang lebih muda ${ }^{12}$. Beberapa ahli perkembangan membedakan antara orang tua muda atau usia tua (usia 65 samai 74 tahun) dan orang tua yang tua atau usia tua akhir (75 tahun atau lebih) ${ }^{13}$.

Kastenbaum $^{14}$ menjelaskan beberapa bentuk kehilangan yang diderita oleh individu yang meninggal dunia, yaitu kehilangan pengalaman, kehilangan hak atas tubuh, kehilangan interaksi dengan orang-orang yang dikasihi dan masih menggantungkan hidupnya kepada individu, kehilangan kesempatan untuk mewujudkan mimpi dan keinginan diri. Comte, $\mathrm{dkk}^{15}$ dan Florian ${ }^{16}, \mathrm{dkk}^{17}$

\footnotetext{
${ }^{12}$ Harimurti. K. (2011). Perawatan usia lanjut di rumah. Komisi Nasional Lanjut Usia. Diunduh 12 Mei 2019, dari www.komnaslansia.or.id/modules

${ }^{13}$ Santrock, J.W. 2002. Life Span Development Perkembangan Masa Hidup. Jakarta: Erlangga.

${ }^{14}$ Kastenbaum, R. (Ed.). (2003). Macmillan encyclopedia of death and dying. New York: The Gale Group.

${ }^{15}$ Conte, H. R. , Weiner, M. B. , \& Plutchik, R. 1982. Measuring Death Anxiety: Conceptual, Personality and Factor Analysis Aspects. Journal of Personality and Social Psychology.

${ }^{16}$ Florian, V. \& Kravets, S. 1983. Fear of Personal Death: Atribution, Structure and Relation to Religion Belief. Journal of Personality and Social Psychology.

${ }^{17}$ Florian, V. \& Kravets, S. 1983. Fear of Personal Death: Atribution, Structure and Relation to Religion Belief. Journal of Personality and Social Psychology.
} 
kecemasan kematian memiliki tujuh aspek, yaitu (1) cemas akan kehilangan pemenuhan diri, (2) cemas akan kehilangan jati diri, (3) cemas akan kehilangan identitas sosial, (4) cemas akan ditinggal oleh keluarga dan sahabat, (5) cemas akan misteri kematian, (6) cemas akan hukuman di akhir jaman, (7) cemas akan penderitaan $^{18}$.

Sejalan dengan hal tersebut Florian dan Mikulincer mengajukan tiga komponen kecemasan terhadap kematian yaitu:

a. Komponen intrapersonal: berhubungan dengan pengaruh yang ditimbulkan terhadap tubuh dan pikiran: seperti kecemasan akan pemenuhan kebutuhan, tujuan pribadi.

b. Komponen interpersonal: berhubungan dengan efek kecemasan terhadap hubungan interpersonal individu.

c. Komponen transpersonal: hal ini berhubungan dengan diri transendental, kecemasan yang akan hukuman di akhirat serta situasi yang harus dijalani setelah meninggal (kehidupan setelah kematian).

Ada banyak penelitian yang dilakukan untuk melihat keterkaitan anatara religiusitas dengan kecemasan akan kematian. Namun hasil penelitian tersebut masih belum konsisten untuk menyimbulkan fenomena ini. Penelitian dari Zida Nusrotina 2017, Muhammad Fakhrurrozi 2008, Via Keteluniati 2017, Siti Muthoharoh dan Fitri Adriani 2014, Kurniasih Ayu Archentari dan Siswati , Aris Pamungkas, Sri Wiyanti dan Rin Widya Agustin, Fitri Efi Nurdinulloh

\footnotetext{
${ }^{18}$ Wijayanti Ari, Lailatushifah Fatmah Siti Noor., Op.Cit.
}

2014, Ernawati dan Sandy Sudarji 2013, Dian Ferenika, Sakti Kaloeti dan Sri Hartati 2017 dan Ananda Ruthnoftali, Yulius Yusak Ranimpi dan M. Aziz Anwar 2017, menyatakan bahwa dua variabel ini terkait secara linear negatif. Religiusitas disimpulkan dapat memberikan bantuan moral kepada lanjut usia dalam menghadapi krisis mental yaitu kecemasan dalam menghadapi kematian atau tutup usia.

Sementara ada beberapa penelitian lain yang menyatakan bahwa tidak ada hubungannya antara religiusitas dengan kecemasan kematian. Seperti penelitian Fauziah Syarifatu Huriah 2016, Yuliana 2015, Wahyu Wicaksono dan Sito meyanto 2003, Ari Wijayanti dan Siti Nur Fatmah Lailatulstifa 2012, dan Retno Fuju Astuti 2018. Penelitian Fauziah Syarifatul Hiriah 2016 lah yang tidak ada hubungan nya karena melihat hubungan religiusitas itu dalam pandangan makna kehidupannya.

Berbagai penelitian terkait fenomena ini sering diteliti di daerah lain (diluar Sumatera Barat). Padahal prokontra seputar keterkaitan dua variabel ini masih menarik untuk diteliti terutama dalam setting masyarakat Sumatera Barat yang terkenal religius. Penelitian ini melihat hubungan antara religiusitas dengan kecemasan kematian pada dewasa tua.

\section{B. LANDASAN TEORI}

A. Defenisi kecemasan kematian

Menurut Tampler kecemasan terhadap kematian merupakan suatu kondisi emosional tidak menyenangkan yang dialami oleh seseorang secara subjektif ketika mulai memikirkan mengenai kematian yang akan dihadapi ${ }^{19}$.

\footnotetext{
${ }^{19}$ Ibid.
} 
Dalam pemahaman ini, Comte, dkk (1982) dan Florian, dkk (1984) kecemasan kematian memiliki tujuh aspek, yaitu (1) cemas akan kehilangan pemenuhan diri, (2) cemas akan kehilangan jati diri, (3) cemas akan kehilangan identitas sosial, (4) cemas akan ditinggal oleh keluarga dan sahabat, (5) cemas akan misteri kematian, (6) cemas akan hukuman di akhir jaman, (7) cemas akan penderitaan $^{20}$.

Kecemasan menghadapi tutup usia disebabkan faktor-faktor lain yaitu seperti faktor fisik, sebagai reaksi antara pikiran dan tubuh yang bisa menimbulkan kecemasan menghadapi tutup usia pada lanjut usia seperti kondisi kesehatan yakni lanjut usia yang sedang menderita penyakit tertentu yang bisa memicu kecemasan faktor psikologis yang berkaitan dengan persepsi diri terhadap kematian, tingkat keterbukaan diri dengan orang-orang sekitar lanjut usia, faktor sosiokultutal yang berkaitan dengan perubahan peranya di dalam keluarga maupun masyarakat, riwayat terjadinya kecemasan terkait dengan tutup usia, perasaan negatif terhadap proses menjadi tua dan tutup usia hubungan yang tidak harmonis dengan keluarga dan lingkungan masyarakat, terbatasnya informasi terkait lanjut usia dan kesejehteraan lanjut usia, kurangnya komunikasi, dan kurangnya aktivitas sosial pada lansia ${ }^{21}$.

Elizabeth Kubler-Ros ${ }^{22}$ (dalam santrock 2002) membagi perilaku dan proses berpikir seseorang yang sekarat

${ }^{20} \mathrm{Ibid}$.

${ }^{21}$ Pamungkas Aris, Dkk. Hubungan Antara Religuisitas dan Dukunga Sosial dengan Kecemasan Menghadapi Tutup Usia Pada Lanjut Usia Pada kKelurahan Jebres Surakarta. Jurnal Pamungkas,et.al.

${ }^{22}$ J.W. Santrock, Op.Cit. menjadi 5 fase: diataranya penolakan dan isolasi, kemrahan, tawar-menawar depresi dan penerimaan.

a. Penolakan dan isolasi, merupakan fase pertama yang diusulkan Kubler-Ross di mana orang menolak bahwa kematian benar-benar ada, Namun penolakan biasannya pertahanan diri yang bersifat sementara dan kemudian akan digantikan dengan rasa penerimaan yang meningkat saat seseorang dihadapkan pada beberapa hal seperti pertimbangan keuangan, urusan yang belum selesai dan kekhawatiran mengenai kehidupan anggota keluarga yang lain nantinya.

b. Kemarahan merupakan fase kedua dimana orang yang menjelang kematian menyadari bahwa penolakan tidak dapat lagi dipertehankan. Penolakan sering memunculkan rasa marah, benci dan iri.

c. Tawar menawar, merupakan fase ketiga menjelang kematian dimana seseorang mengembangkan harapan bahwa kematian sewaktu-waktu dapat ditunda atau diundur.

d. Depresi merupakan fase keempat menjelang kematian di mana orang yang sekarat akhirnya menerima kematian. Pada titik ini, suatu periode depresi atau persiapan berduka mungkin muncul.

e. Penerimaan merupakan fase kelima menjelang kematian, dimana seseorang mengembangkan rasa damai, menerima takdir dan dalam beberapa hal ingin ditinggal sendiri.

\section{B. Defenisi Dewasa Tua}

Pada umumnya psikolog menetapkan sekitar usia 20 tahun sebagai 
dewasa awal masa dewasa dan berlangsung sampai sekitar usia 40-45 dan pertengahan masa dewasa berlangsung dari sekitar usia 40-45 sampai sekitar usia 65 tahun, serta masa dewasa lanjut atau masa tua berlangsung dari sekitar usia 65 tahun sampai meninggal. Sementara itu Erikson menyebutkan ciri-ciri masa tua atau lanjut usia merupakan masa akhir kehidupan seseorang, yang ditandai dengan perkembangan seseorang kearah itegritas ego ataupun putus asa ${ }^{23}$.

\section{Defenisi Religuisitas}

Religio adalah sikap kekhidmatan dalam pemujaan. Sedangkan religiositas dimaknakan sebagai pengabdian terhadap agama, kesalehan. Religiositas adalah inti kualitas hidup manusia, dan harus dimaknakan sebagai rasa rindu, rasa ingin bersatu, rasa ingin berada dengan yang abstrak. Sementara itu Nurcholish Majdid menyatakan, bahwa religiositas adalah tingkah laku yang sepenuhnya dibentuk oleh kepercayaan kepada ke gaiban atau alam gaib, yaitu kenyataan-kenyataan yang supra empiris.

Dalam Jalaluddin $^{24}$ religiusitas ini berhubungan dengan tingkah laku keagamaan. Bentuk tingkah laku yang bersumber dari keyakinan beragama. Karena itu religiositas menyangkut banyak faktor, baik yang bersifat intern maupun ekstern. Dalam pandangan Glock dan Stark. Menurut keduanya riligiositas memiliki lima dimensi sebagai berikut:

1. Dimensi keyakinan adalah berisi pengharapan-pengharapan di mana orang religius berpegang teguh pada

\footnotetext{
${ }^{23}$ Desmita. $\quad 2015 . \quad$ Psikologi Perkembangan. Bandung: PT Remaja Rosdakarya.

${ }^{24}$ Jalaluddin. 2016. Psikologi Agama Memahami Perilaku dan Prinsip-Prinsip Psikologi. Jakarta: PT Gaja Grafindo Persada.
}

paradigma teologis tertentu dan mengikuti kebenaran dokrin-dokrin tersebut. Setiap agama mempertahankan seperangkat kepercayaan dimana para penganut diharapkan akan taat. Walaupun demikian, isi dan ruang lingkup keyakinan bervariasi tidak hanya di anatara agama-agama, tetapi sering juga di antara tradisi-tradisi dalam agama yang sama.

2. Dimensi Praktik agama mencakup perilaku pemujaan, ketaatan dan halhal yang dilakukan orang untuk menunjukkan komitmen terhadap agama yang dianutnya. Praktik agama ini terdiri dari ritual dan ketaan ritual mengacu kepada seperangkat ritus, tindak keagamaan formal dan praktikpraktik suci yang dilakukan para pemeluknya. Ketaatan dan ritual bagaikan ikan dengan air. Apabila aspek ritual sangat formal dan khas publik, semua agama yang dikenal juga mempunyai perangkat tindakan persembahan dan kontemplasi personal yang relatif spontan, informal dan khas pribadi sebagaimana yang dijelaskan dalam Q.S.18: 110 yang berbunyi:

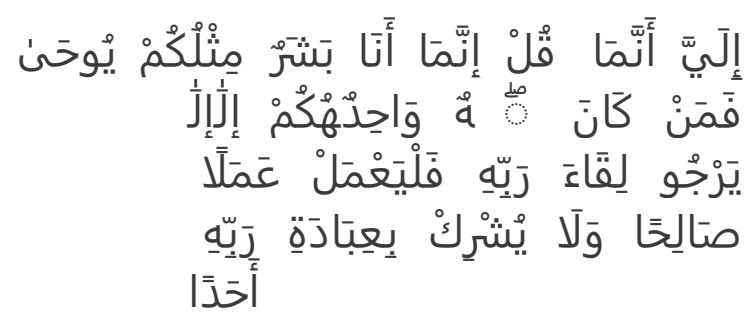

Artinya: Katakanlah, sesungguhnya aku ini manusia biasa seperti kamu, yang diwahyukan kepadaku: "Bahwa Sesungguhnya Tuhan kamu itu adalah Tuhan yang Esa". Barangsiapa mengharap perjumpaan dengan Tuhannya, 


$\begin{array}{lr}\text { Maka hendaklah } & \text { ia } \\ \text { mengerjakan amal yang } & \text { saleh } \\ \text { dan janganlah } & \text { ia } \\ \text { mempersekutukan seorangpun } \\ \text { dalam beribadat repada } \\ \text { Tuhannya". }\end{array}$

Dimensi ini ibarat batang dari sebuah pohon. Kekuatan batang merupakan hal yang tidak boleh diabaikan dalam berdirinya sebuah pohon. Begitu juga dengan ibadah dalam kehidupan beragama seseorang.

3. Dimensi Ritualitas (Ritualistic Dimention) yaitu tingkatan sejauh mana seseorang mengerjakan kewajiban-kewajiban ritual dalam agamanya. Misalnya sholat,zakat,berpuasa,dan haji.

4. Dimensi Pengalaman (experiential dimention) yaitu perasaan-perasaan atau pengalaman-pengalaman keagamaan yang pernah dialami dan dirasakan misalnya persaan dekat dengan tuhan,merasa dilindungi tuhan,dan merasa doanya dikabulkan tuhan.

5. Dimensi konsekkuensi (consequential Dimention) yaitu dimensi yang diukur sejauh mana prilaku seseorang domotivasi oleh ajaran agamanya didalam kehidupan sosial. Misalnya apakah dia menjenguk temannya yang sakit dan membantu teman yang sedang mengalami kesusahan.

\section{METODOLOGI PENELITIAN}

Penelitian ini menggunakan dua variabel yaitu variabel kecemasan sebagai variabel terikat dan religiusitas sebagai variabel bebas. Data dikumpulkan melalui skala psikologi yang terdiri dari skala kecemasan dan skala religiusitas. Skala kecemasan disusun berdasarkan aspekaspek kecemasan kematian yang dikemukakan oleh Comte, dkk (1982) dan Florian, $\mathrm{dkk}^{25}$ (1984) yang memiliki tujuh aspek, yaitu (1) cemas akan kehilangan pemenuhan diri, (2) cemas akan kehilangan jati diri, (3) cemas akan kehilangan identitas sosial, (4) cemas akan ditinggal oleh keluarga dan sahabat, (5) cemas akan misteri kematian, (6) cemas akan hukuman di akhir jaman, (7) cemas akan penderitaan. Sementara skala religiusitas disusun berdasarkan dimensi yang dipaparkan oleh Glock dan Stark, yang mana sebanyak 5 buah dimensi, yaitu : (1) dimensi keyakinan, (2) dimensi praktik agama, (3) dimensi penghayatan, (4) dimensi pengalaman, dan (5) dimensi pengetahuan agama ${ }^{26}$. Alat ukur diuji coba dan dinilai validitasnya dengan expert judgment dan reliabilitasnya diukur melalui uji alpha cronbach. Aitem direvisi sesuai dengan hasil uji coba untuk kemudian digunakan sebagai skala penelitian.

Hasil uji validitas pada variabel religiusitas (r) didapatkan hasil bahwa 38 butir pernyataan religiusitas, 33 aitem dinyatakan valid atau $>0,20$. Sedangkan 5 aitem dinyatakan tidak valid atau $<0,20$, dan aitem yang tidak valid tidak akan dimasukkan pada penelitian selanjutnya. Dengan demikian skala religiusitas dapat dikatakan andal dan dapat digunakan sebagai instrumen penelitian karena telah memenuhi persyaratan validitas dan reliabilitasnya. Sedangkan Hasil uji validitas pada variabel kecemasan kematian (kk) didapatkan hasil bahwa 22

\footnotetext{
${ }^{25}$ H. R. Conte, dan V. Florian, \& Kravets, S. Op.Cit.

${ }^{26}$ D. Ancok, \& Suroso, F.N. (2001). Psikologi islami. Yogyakarta: Pustaka Pelajar.
} 
butir pernyataan religiusitas, 21 aitem dinyatakan valid atau $>0,20$. Sedangkan 1 aitem dinyatakan tidak valid atau $<0,20$, namun penulis menambahkan 1 aitem lagi menjadi 23 aitem dan aitem yang tidak valid tidak akan dimasukkan pada penelitian selanjutnya. Dengan demikian skala religiusitas dapat dikatakan andal dan dapat digunakan sebagai instrumen penelitian karena telah memenuhi persyaratan validitas dan reliabilitasnya.

Pada penelitian ini, pengujian reabilitas instrumen dengan menggunakan teknik alpha cron bach aplikasi SPPS versi 24. Reliabilitas yang kurang dari 0,6 adalah kurang baik. Sedangkan 0,7 dapat diterima dan diatas 0,8 adalah baik. Berdasarkan uji reliabilitas menggunakan rumus alpha dapat dilihat pada tabel berikut :

\section{Reability Statistics Religiusitas Reliability Statistics}

Cronbach's

\begin{tabular}{l|l} 
Alpha & N of Items \\
\hline, 815 & 33 \\
\hline
\end{tabular}

\section{Reability Statistics Kecemasan Kematian}

\begin{tabular}{l|l}
$\begin{array}{l}\text { Reliability Statistics } \\
\text { Cronbach's } \\
\text { Alpha }\end{array}$ & N of Items \\
\hline, 811 & 23 \\
\hline
\end{tabular}

Berdasarkan tabel diatas maka di peroleh nilai $r=0,815$ untuk religiusitas. Kemudian untuk kecemasan kematian didapatkan $\mathrm{r}=0,811$. Hasil tersebut menunjukkan bahwa skala religiusitas dan kecemasan kematian reliabel, sehingga dapat digunakan sebagai alat ukur.

Teknik analisis yang digunakan dalam penelitian ini adalah teknik analisis korelasi sederhana, yaitu untuk hubungan satu variabel terhadap variabel lainnya dengan menggunakan Stastistikal Program for Social Science (SPSS) versi 24. Data yang telah diperoleh diolah dan dianalisis sesuai dengan tujuan penelitian untuk melihat apakah ada hubungan antara religiusitas dengan kecemasan kematian menggunakan teknik analisis korelasipearson (product moment pearson), yaitu analisis untuk mengukur keeratan hubungan secara linear antara dua variabel yang mempunyai distribusi normal. Namun sebelumnya dilakukan uji normalitas data dengan kolmogorov smirnov.

\section{HASIL PENELITIAN DAN PEMBAHASAN}

Kategori Subjek Berdasarkan Variabel yang Diteliti

Berdasarkan skala religiusitas yang diberikan pada 48 subjek yang diteliti sebanyak 35 orang memiliki tingkat religiusitas yang tinggi dan 13 orang memiliki tingkat religiusitas yang rendah. Hasil ini menunjukan bahwa mayoritas subjek memiliki tingkat religiusitas yang tinggi. Sementara skala kecemasan menunjukan bahwa 18 orang cemas terhadap kematian dan 30 orang tidak cemas terhadap kematian. Hasil ini secara umum menunjukan bahwa dewasa tua memiliki tingkat kecemasan kematian yang rendah.

\section{Analisis Data}

a. Uji Normalitas

Berdasarkan pengolahan data dengan menggunakan spss, maka diperoleh hasil normalitas sebagai berikut. Kriteria pengujiannya adalah signivikan> 0,05 maka data terdistribusi normal. Indeks kolmogorov smirnov dari table skala religiusitas adalah 0,815 dan 
kecemasan kematian adalah 0,811 yang berarti besar dari 0,05. Jadi, dapat disimpulkan bahwa data religiusitas dan data kevemasan kematian juga berdistribusi normal sehingga dapat dilakukan uji statistik selanjutnya yaitu uji linearitas dan hipotesis.

b. Uji Uji Hipotesis

Uji hipotesis dilakukan dengan menggunakan analisis kolerasi pearson digunakan untuk mengukur apakah ada hubungan yang erat diantara dua variable tersebut dalam penelitian ini akan mengukur bagaimana hubungan religiusitas dengan kecemasan kematian pada dewasa tua. Berdasarkan hasil penelitian dengan menggunakan program SPSS, menunjukan bahwa nilai koefisien pearson corelation religiusitas dengan kecemasan kematian sebesar 0,8. Hasil ini membuktikan bahwa tidak ada hubungan antara religiusitas dengan kecemasan kematian pada dewasa tua.

\section{E. KESIMPULAN}

Bagi
kematangan lanjut usia,
seseorang lebih dibicarakan dibandingkan tahun-tahun sebelumnya. Pemikiran dan pembicaraan mengenai kematian meningkat, perkembangan integritas pun meningkat melalui peninjauan hidup yang pisitif dan hal ini dapat membantu mereka untuk menerima kematian. Sebagian besar lansia banyak mengatakan ia siap untuk menyongsong kematian dan sebagian orang mengatakan bahwa kematian akan menjadi suatu interpurasi yang menyedihkan kerena ia akan kehilangan partisipasinya dalam aktivitas dan hubungan sosial $^{27}$. Kecemasan yang terjadi pada lansia diasumsikan lebih kepada perasaan harus meninggalkan pasangan hidup dan keluarga. Penelitian yang dilakukan Larson, menunjukkan bahwa lanjut usia yang lebih religius, lebih tenang dan tabah dalam menghadapi kematian. Meski dalam Alquran telah diterangkan bahwa kematian tidak memandang usia seperti ditegaskan Allah dalam Surat Al-Ankabut Ayat 57:

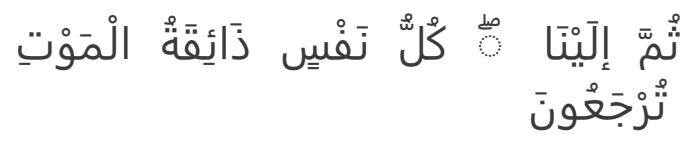

Artinya: "Tiap-tiap yang berjiwa akan merasakan mati. Kemudian hanyalah kepada Kami kamu dikembalikan”.

Namun tidak dapat dipungkiri bahwa manusia pada rentang usia dewasa tua memiliki kesadaran akan dekatnya kematian kepada diri mereka. Kondisi yang akhirnya berpotensi memunculkan kecemasan. Bila hal ini berlanjut maka fokus untuk mempersiapkan kematian dengan berbuat banyak kebaikkan bisa saja menjadi sulit untuk dilakukan. Hasil ini membuktikan bahwa orang yang religius bukan berarti memiliki kecemasan yang tinggi atau justru rendah akan datangnya kematian. Penelitian ini menunjukan tidak ada hubungan antara religiusitas dengan kecemasan kematian, namun belum tentu religiusitas yang tinggi menyebabkan kecemasan kematian yang tinggi juga. Tingginya religiusitas tidak selalu menjadi faktor seseorang menjadi cemas terhadap kematian atau

\footnotetext{
${ }^{27}$ Santrock, J.W. 2002. Life Span Development Perkembangan Masa Hidup. Jakarta: Erlangga.
} 
bahkan rendahnya religiusitas juga tidak menjadikan salah seorang itu juga tidak cemas terhadap kematian. Semua mahluk hidup pasti akan merasakan kematian. Kecemasan pada taraf tertentu dibutuhkan agar manusia mampu mengevaluasi tentang segala hal yang akan dilakukannya di dunia. Persiapan kematian terkait dengan kewajiban mengimplementasikan ajaran agama pada kehidupan sehari-hari.

\section{DAFTAR KEPUSTAKAAN}

Adriani Fitri, Muthoharoh Siti.2014. Hubungan antara Religuisitas dengan Kecemasan Kematian pada Dewasa Tengah. Jurnal Psikologi kepribadian dan Sosial Vol.03.01,April 2014.

Ancok, D. \& Suroso, F. N. 2005. Psikologi Islami: Solusi Islam Atas Problem- Problem Psikologi. Yogyakarta: Pustaka Pelajar.

Ancok, D., \& Suroso, F.N. (2001). Psikologi islami. Yogyakarta: Pustaka Pelajar.

Archentri Ayu Kurniasih, Siswati. Hubungan Antara Religuisitas Dengan Kecemasan Terhadap Kematian Pada Individu Fase Dewasa Madya Di PT Tiga Serankai Group.

Chamberlain, T.J., \& Hall, C.A. (2000). Realized religion. Radnor: Templetin Foundation Press.

Conte, H. R. , Weiner, M. B. , \& Plutchik, R. 1982. Measuring Death Anxiety: Conceptual, Personality and Factor Analysis Aspects. Journal of Personality and Social Psychology.

Desmita. 2015. Psikologi Perkembangan. Bandung: PT Remaja Rosdakarya.
Fakhrurrozi Muhammad.2008. Hubungan Antara Religuisitas Dengan Death Anxiety : Study Meta Analisis. Jurnal Psikologika vol.13 No. 25- Januari 2008.

Firestone, R., Catlett, J. (2009). Beyond death anxiety. New York: Springer.

Florian, V. \& Kravets, S. 1983. Fear of Personal Death: Atribution, Structure and Relation to Religion Belief. Journal of Personality and Social Psychology.

Ghufron dan Risnawati (2010). Teoriteori psikologi. Jogjakarta: ArRuzz Media Group.

Hidayat, K. (2013). Psikologi kematian. Jakarta: Noura Books.

Huriyah Syarifatul Fauzia.2016. Pengaruh Religiusitas Terhadap Death Anxiety Dimediasi Pada Muslim Dewasa Madya Di Kabupaten Tasik Malaya. Jurnal Repository upi.edu.

Harimurti. K. (2011). Perawatan usia lanjut di rumah. Komisi Nasional Lanjut Usia. Diunduh 12 Mei 2019, dari www.komnaslansia.or.id/module s.

Kastenbaum, R. (Ed.). (2003). Macmillan encyclopedia of death and dying. New York: The Gale Group.

Jalaluddin. 2016. Psikologi Agama Memahami Perilaku dan PrinsipPrinsip Psikologi. Jakarta: PT Gaja Grafindo Persada.

Kateluniati Via. 2017. Religuisitas Sebagai Prediktor Kecemasan Menghadapi Kematian Pada Penatua Dan Diakon Jemaat Gke Tamiang Layang.

Lemming, D.A., Madde, K., \& Marlan, S. (Ed.). (2010). Encyclopedia of 
psychology and religion. New

York: Springer.

Newfield, S.A., Hinz, M.D., Tilley, D.S., Sridaromont, K.L., \& Maramba, P.J. (2007). Nursing diagnosis adult, child, women's, mental health, gerontic, and home health considerations. Philadelphia: F.A. Davis Company.

Pamungkas Aris, Dkk. Hubungan Antara Religuisitas dan Dukunga Sosial dengan Kecemasan Menghadapi Tutup Usia Pada Lanjut Usia Pada kKelurahan Jebres Surakarta. Jurnal Pamungkas,et.al.

Santrock, J.W. 2002. Life Span Development Perkembangan Masa Hidup. Jakarta: Erlangga.

Shepard, J.M. (2013). Sociology. Belmont: Wadsworth Cengange Learning.

Wen, Y. (2010). Religiosity and Death Anxiety. The Journal of Human Resource and Adult Learning, Vol. 6 (2): 31-37.

Sudarji Shanty Ermawati. 2013. Kecemasan Menghadapi Kematian Pada Lanjut Usia. Jurnal Psibernetika.

Wicaksono Wahyu. 2003. Ketakutan Terhadap Kematian Ditinjau Dari Kebijaksanaan Dan Orientasi Religius Pada Periode Akhir Yang Berstatus Mahasiswa. Jurnal Psikologi.

Wijayanti Ari, Lailatushifah Fatmah Siti Noor. 2012. Keberagamaan Hidup Dan Kecemasan Terhadap Kematian Terhadap Kematian Pada Orang Dengan Diabetes Meletus. Jurnal Insight Volume 10, No 1, Februari 2012. 